\title{
Geochemistry of Outcrop Samples from the Raven Canyon and Paintbrush Canyon Reference Sections, Yucca Mountain, Nevada
}

by Zell E. Peterman and R.W. Spengler, U.S. Geological Survey; and F.R. Singer and R.P. Dickerson, Science Applications International, Corp.

\section{U.S. GEOLOGICAL SURVEY}

Open-File Report 94-550

Prepared in cooperation with the

NEVADA OPERATIONS OFFICE

U.S. DEPARTMENT OF ENERGY, under

Interagency Agreement DE-A108-92NV10874

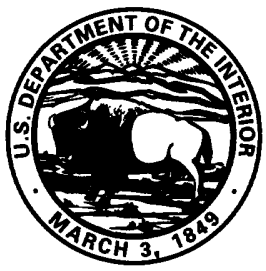




\section{U.S. DEPARTMENT OF THE INTERIOR}

BRUCE BABBITT, Secretary

U.S. GEOLOGICAL SURVEY

Gordon P. Eaton, Director

The use of trade, product, industry, or firm names is for descriptive purposes only and does not imply endorsement by the U.S. Government.

For additional information write to:

Chief, Earth Science Investigations

Program

Yucca Mountain Project Branch

U.S. Geological Survey

Box 25046, MS 421

Denver Federal Center

Denver, CO 80225
Copies of this report can be purchased from:

U.S. Geological Survey

Earth Science Information Center

Open-File Reports Section

Box 25286, MS 517

Denver Federal Center

Denver, CO 80225 


\section{CONTENTS}

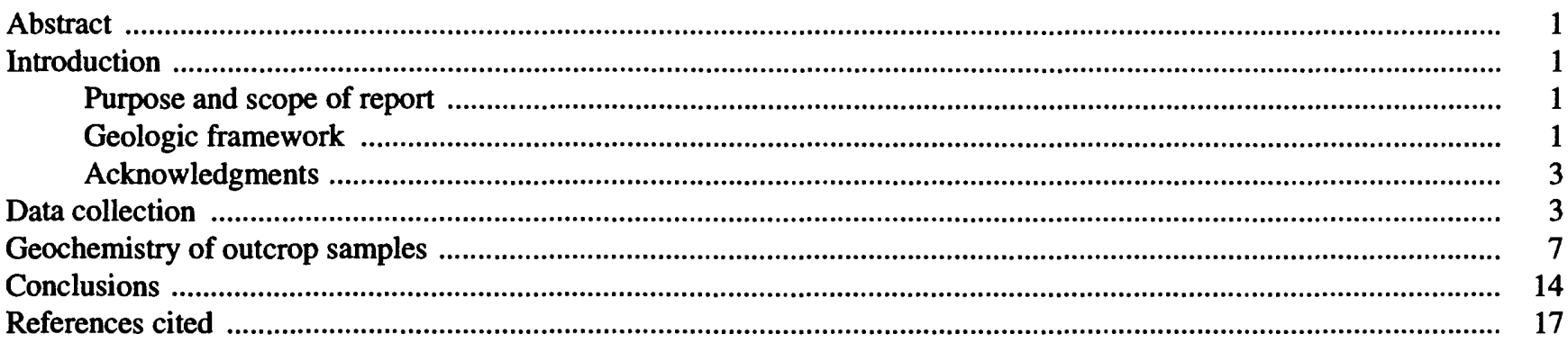

FIGURES

1. Map showing generalized geology of the Yucca Mountain area and the locations of the Raven Canyon and Paintbrush Canyon reference sections.

2-8. Graphs showing:

2. Concentrations of zirconium and titanium in samples from the Raven Canyon reference section...................... 9

3. Concentrations of calcium, strontium, and barium in samples from the Raven Canyon reference section .......... 10

4. Concentrations of yttrium, lanthanum, and cerium in samples from the Raven Canyon reference section ......... 11

5. Concentrations of potassium, niobium, and rubidium in samples from the Raven Canyon reference section..... 12

6. Ratios of rubidium to strontium $(\mathrm{Rb} / \mathrm{Sr})$, calcium to strontium $(\mathrm{Ca} / \mathrm{Sr})$, and potassium to rubidium $(\mathrm{K} / \mathrm{Rb})$ in samples from the Raven Canyon reference section.................................................................................. 13

7. Present-day and initial ${ }^{87} \mathrm{Sr} /{ }^{86} \mathrm{Sr}$ values for samples from the Raven Canyon and Paintbrush Canyon reference sections

8. IR(Sr) values versus reciprocal strontium concentrations for samples from the Raven Canyon and Paintbrush Canyon reference sections.....

\section{TABLES}

1. Geochemical data for samples from the Raven Canyon reference section, Yucca Mountain, Nevada

2. Geochemical data for samples of the Calico Hills Formation from the Paintbrush Canyon reference section, Yucca Mountain, Nevada.

3. Strontium-isotope data for samples from the Raven Canyon and Paintbrush Canyon reference sections

\section{CONVERSION FACTORS AND VERTICAL DATUM}

\begin{tabular}{|c|c|c|}
\hline Multiply & By & To obtain \\
\hline $\begin{array}{r}\text { foot }(\mathrm{ft}) \\
\operatorname{gram}(\mathrm{g}) \\
\text { kilometer }(\mathbf{k m}) \\
\operatorname{meter}(\mathrm{m}) \\
\text { millimeter }(\mathrm{mm})\end{array}$ & $\begin{array}{l}0.3048 \\
0.03527 \\
0.6214 \\
3.281 \\
0.03937\end{array}$ & $\begin{array}{l}\text { meter }(\mathrm{m}) \\
\text { ounce }(\mathrm{oz}) \\
\text { mile (mi) } \\
\text { feet (ft) } \\
\text { inch (in) }\end{array}$ \\
\hline
\end{tabular}

Degree Celsius $\left({ }^{\circ} \mathrm{C}\right)$ may be converted to degree Fahrenheit $\left({ }^{\circ} \mathrm{F}\right)$ by using the following equation:

$$
{ }^{\circ} \mathrm{F}=9 / 5\left({ }^{\circ} \mathrm{C}\right)+32 \text {. }
$$

Sea level: In this report "sea level" refers to the National Geodetic Vertical Datum of 1929 (NGVD of 1929)-a geodetic datum derived from a general adjustment of the first-order level nets of both the United States and Canada, formerly called Sea Level Datum of 1929. 


\title{
Geochemistry of Outcrop Samples from the Raven Canyon and Paintbrush Canyon Reference Sections, Yucca Mountain, Nevada
}

\author{
By Zell E. Peterman, R.W. Spengler, F.R. Singer, andR.P. Dickerson
}

\section{Abstract}

As part of the site characterization studies being conducted by the U.S. Geological Survey at Yucca Mountain, Nevada, reference stratigraphic sections were established in outcrop areas where the volcanic rocks of Miocene age have been minimally altered. Beneath most of Yucca Mountain tuffs of the Calico Hills Formation, tuffs of the Crater Flat Group, and older tuffs, recognized only in drill core, have been pervasively altered to zeolites and other low-temperature, secondary minerals. Previous studies have indicated that opensystem (nonisochemical) conditions prevailed during this alteration largely obscuring the original compositions and textures of these units. The reference sections were sampled to obtain critical geochemical and isotopic baseline data for characterizing the primary compositions of the rock units and for assessing the degree and extent of element mobility attendant with the past alteration of the rock mass. The open-system alteration of the prePaintbrush Group units may serve as a useful analogue for alteration that could occur in the Topopah Spring Tuff in the near field of the potential repository due to thermal loading.

\section{INTRODUCTION}

The Yucca Mountain area in southern Nevada (fig. 1) is being evaluated for its suitability as a potential site for the construction of an underground, highlevel nuclear waste repository (U.S. Department of Energy, 1988). With support from the Department of Energy Yucca Mountain Site Characterization Project under Interagency Agreement No. DE-AI0892NV10874, the U.S. Geological Survey (USGS) is conducting detailed petrographic, geochemical, and isotopic analyses of samples collected from drill cores and from outcrops. The geochemical and isotopic compositions of the volcanic rocks of Yucca Mountain derive from those of their parental magmas, from changes resulting from the eruptive processes and from post-depositional alteration. In this study, geochemical and isotopic data were acquired on samples from reference sections selected in areas where the effects of the post-depositional alteration has been minimal. These data will be used as baseline information for delineating and correlating zonal features in the volcanic rock units, and for assessing possible future open-system alteration (chemical changes) that may occur in the thermal aureole of the potential repository after it has been loaded with nuclear waste.

\section{Purpose and Scope of Report}

Geochemical and isotopic data are reported for 76 rock samples from the Raven Canyon and Paintbrush Canyon reference sections. A major goal of this study is to establish baseline geochemical and isotopic data for relatively unaltered, nonwelded to densely welded zones of the various rock units that compose the volcanic stratigraphy at Yucca Mountain. These data are acquired by locating and sampling outcrops where the rocks have been minimally affected by the regional alteration described by Broxton and others (1987). Unaltered vitric and devitrified tuffs in the Prow Pass and Bullfrog Tuffs of the Crater Flat Group and in younger units are present in Raven Canyon at the southernmost end of Yucca Mountain near Highway 95 (fig. 1), and vitric tuffs in Calico Hills Formation crop out in Paintbrush Canyon (fig. 1). The data in this report were previously compared with data for core samples from UE-25a \#1 and UE-25b \#1 to assess the degree and extent of element mobility during alteration of the volcanic units (Peterman and others, 1993).

\section{Geologic Framework}

The rock mass at Yucca Mountain (fig. 1) consists of a thick sequence of rhyolitic tuffs and lavas of Miocene age (Spengler and Fox, 1989). These units range in numerical age from about 11.5 to $14.0 \mathrm{Ma}$ 


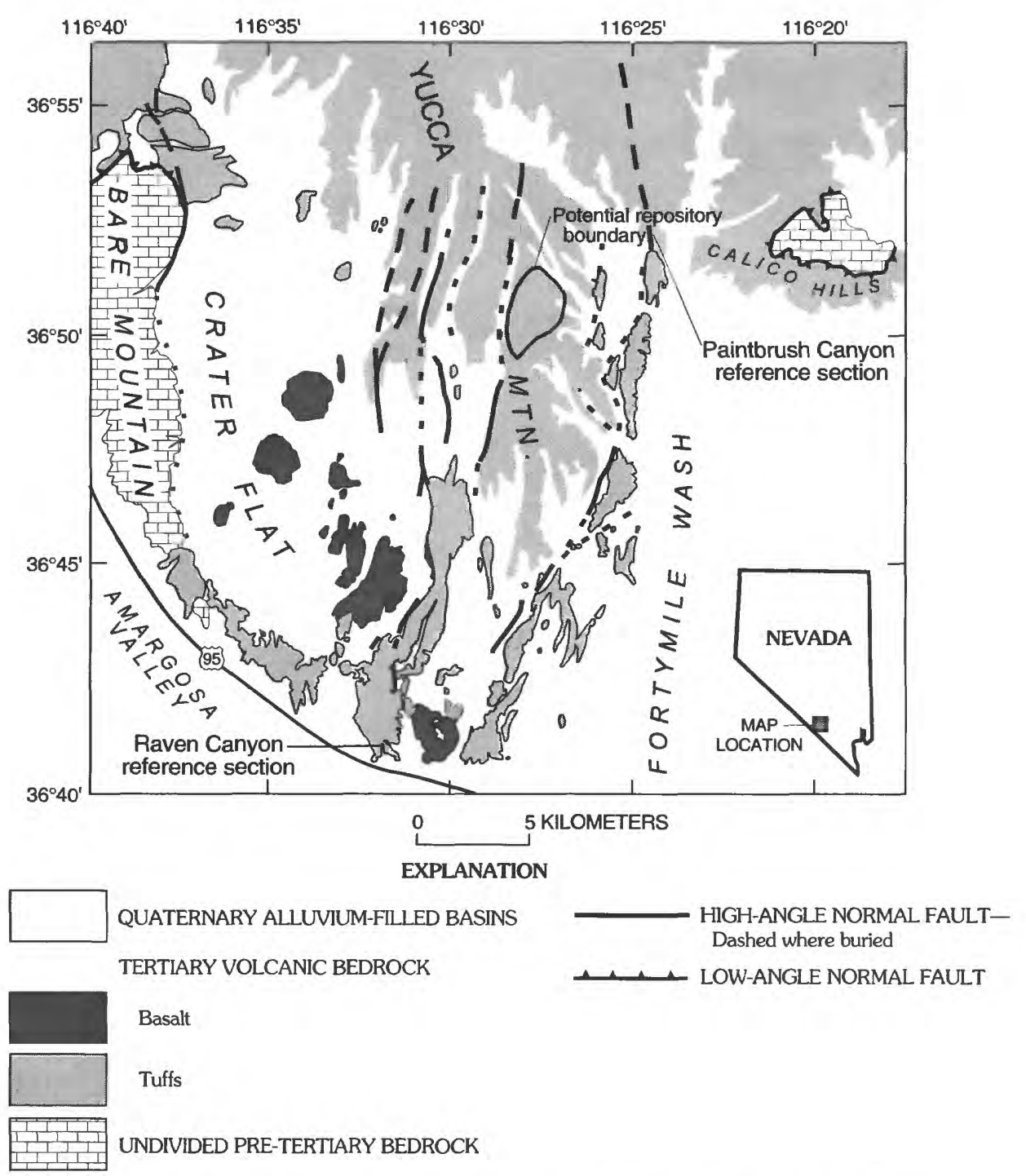

Figure 1. Generalized geology of the Yucca Mountain area and the locations of the Raven Canyon and Paintbrush Canyon reference sections.

(million years before the present). As much as $3 \mathrm{~km}$ of the volcanic section may exist beneath the potential repository level, which is in the Topopah Spring Tuff. The upper $500 \mathrm{~m}$ of the sequence is above the water table and generally consists of a thick zone of welded tuff underlain by nonwelded to partially welded tuff. Much of the nonwelded to partially welded tuffs in the unsaturated zone, including the Calico Hills Formation and part of the Prow Pass and Bullfrog Tuffs of the Crater Flat Group, has been extensively altered to zeolites (Broxton and others, 1987). All of the units below the water table are severely altered. The mineralogic and geochemical effects associated with this past alteration are being studied at the Los Alamos National Laboratory (Broxton and others, 1987; Broxton, 1992). The
USGS (Peterman and others, 1991; Peterman and others, 1993; Spengler and Peterman, 1991) is using isotope and trace element geochemistry to characterize the vertical and lateral variability of the rock units including the degree and extent of element mobility in the past.

Potassium-argon ages of authigenic illite and stratigraphic relationships indicate that the regional alteration occurred within a few million years of the time of eruption and deposition of the volcanic rocks (Broxton and others, 1987). However, K-Ar dating of zeolites (WoldeGabriel and others, 1992) yielded a wide spectrum of ages. The conditions under which zeolites retain argon are not known although zeolites clearly are less retentive than illite. Nonetheless, the 
spectrum of K-Ar zeolite ages may be reflecting susceptibility of the rock mass to low-temperature modification long after the main episode of alteration.

An understanding of the isotopic and chemical changes that occurred during diagenesis could be useful for predicting possible future changes that may occur in the near field of the potential repository if pore or perched water is mobilized during heating of the rock mass by the nuclear waste. Rock intervals that are rich in zeolites, such as the Calico Hills Formation, may function as important natural barriers to the migration of certain radionuclides between the potential repository level and the water table (Herbst and Canepa, 1989). However, the presence of zeolites also may complicate the performance of the natural system which is the final barrier to the release of radionuclides to the environment. The zeolitized rocks contain substantial amounts of water that can be released at temperatures greater than $80^{\circ} \mathrm{C}$ (Bish, 1990). During loading of the potential repository and heating of the surrounding rocks, water could be released from the Calico Hills Formation and from zeolitized zones in the Topopah Spring Tuff. This dehydration would be accompanied by a volume decrease of a given mass of rock which could potentially lead to increased permeability (Bish, 1990). If the heated water resulting from dehydration were to move into the previously unaltered Topopah Spring Tuff in the near field of the potential repository, secondary minerals could form. Presumably, the lower vitrophyre of the Topopah Spring Tuff would be especially vulnerable to such alteration (Levy and O'Neil, 1989; Peterman and others, 1991). This process could be important to the performance of the potential repository because the increase in specific rock volume associated with the formation of lower density secondary minerals would tend to seal fractures and decrease permeability. Furthermore, zeolites formed within this alteration halo could be an additional barrier to the migration of radionuclides, particularly ${ }^{90} \mathrm{Sr}$ and ${ }^{137} \mathrm{Cs}$.

\section{Acknowledgments}

Duane Craft, Shannon Mahan, and Kiyoto Futa provided outstanding technical support in sample preparation, X-ray fluorescence analyses, and isotopic analyses. Thomas C. Moyer and Jeffrey K. Geslin, both of Science Applications International Corporation, reviewed the report and provided numerous helpful suggestions.

\section{DATA COLLECTION}

At the Raven Canyon reference section (fig. 1) samples were collected along three traverses that collectively intercepted a stratigraphic thickness of approximately $1,100 \mathrm{ft}$ of the Tram, Bullfrog, Prow Pass, Wahmonie, and Topopah Spring Tuffs. The lower part of the reference section (bedded tuff and Tram Tuff) was measured using a Jacob's staff and was designated traverse A. The middle part of the reference section (bedded tuff and Bullfrog Tuff), in Raven Canyon proper, was measured by tape and compass traverse and was designated traverse $B$. The upper part of the reference section (bedded tuff, Prow Pass, Wahmonie, and Topopah Spring Tuff) was measured using a Jacob's staff and by tape and compass and was designated traverse $C$. Coordinates of the starting points (lowest stratigraphic positions) of the Raven Canyon traverses were estimated from the Big Dune 7.5 minute quadrangle relative to the 1927 North American Datum: traverse A, 38 $8^{\circ} 41.2^{\prime} \mathrm{N}$ and $116^{\circ} 32.7^{\prime} \mathrm{W}$; traverse $\mathrm{B}, 38^{\circ} 41.1^{\prime} \mathrm{N}$ and $116^{\circ} 32.3^{\prime} \mathrm{W}$; and traverse $\mathrm{C}$, $38^{\circ} 41.4^{\prime} \mathrm{N}$ and $116^{\circ} 32.1^{\prime} \mathrm{W}$. At the Paintbrush Canyon reference section, samples of the Calico Hills Formation were collected along a single traverse that intercepted approximately $600 \mathrm{ft}$ of section. Coordinates of the starting point (base) of the Paintbrush Canyon section were estimated from the Topopah Spring NW 7.5 minute quadrangle: $116^{\circ} 24.8^{\prime} \mathrm{W}$ and $36^{\circ} 54.7^{\prime} \mathrm{N}$. The Paintbrush Canyon section was measured using a Jacob's staff.

Soil and bedrock surfaces and near-surface fractures in this region are permeated by pedogenic calcite that contains both $\mathrm{Ca}$ and $\mathrm{Sr}$. To remove the calcite, samples were coarsely crushed to fragments approximately $5 \mathrm{~mm}$ or smaller, treated with $0.1 \mathrm{~N}$ hydrochloric acid until reaction with calcite ceased, repeatedly rinsed with deionized water, and then dried before pulverization to approximately 200 mesh in a Spex shatterbox mill. This mild acid leaching removes the calcite but does not have an appreciable effect on the silicate minerals. Major and trace elements were determined by energy-dispersive, $\mathrm{X}$-ray fluorescence on 3-to 5-gram splits of the 200-mesh bulk-rock samples. Multiple secondary targets and USGS rock standards were used to analyze for $\mathrm{K}, \mathrm{Ca}, \mathrm{Ti}, \mathrm{Rb}, \mathrm{Sr}, \mathrm{Y}, \mathrm{Zr}, \mathrm{Nb}$, $\mathrm{Ba}, \mathrm{La}$, and $\mathrm{Ce}$ concentrations in the samples (tables 1 and 2). Replicate analyses of USGS rock standard GSP-1 yield the following coefficients of variation: $\mathrm{K}, \pm 1.2$ percent; $\mathrm{Ca}, \pm 3.7$ percent; $\mathrm{Ti}, \pm 2.4$ percent; $\mathrm{Rb}, \pm 1.4$ percent; $\mathrm{Sr}, \pm 1.3$ percent; $\mathrm{Y}, \pm 8.3$ percent; $\mathrm{Zr}, \pm 3.6$ percent; $\mathrm{Nb}, \pm 3.7$ percent; $\mathrm{Ba}, \pm 2.9$ percent; $\mathrm{La}, \pm 7.1$ percent; and $\mathrm{Ce}, \pm 3.9$ percent. 


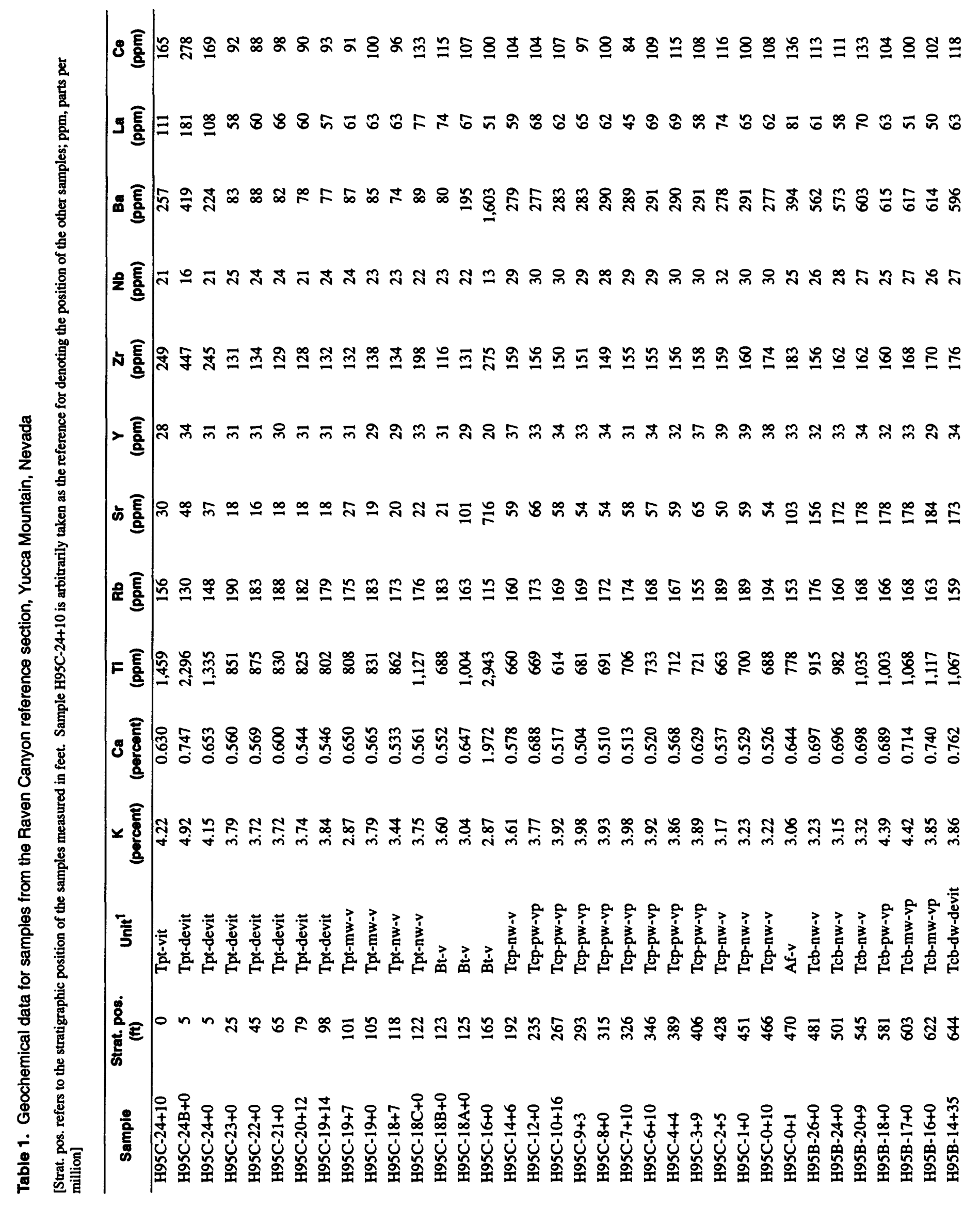




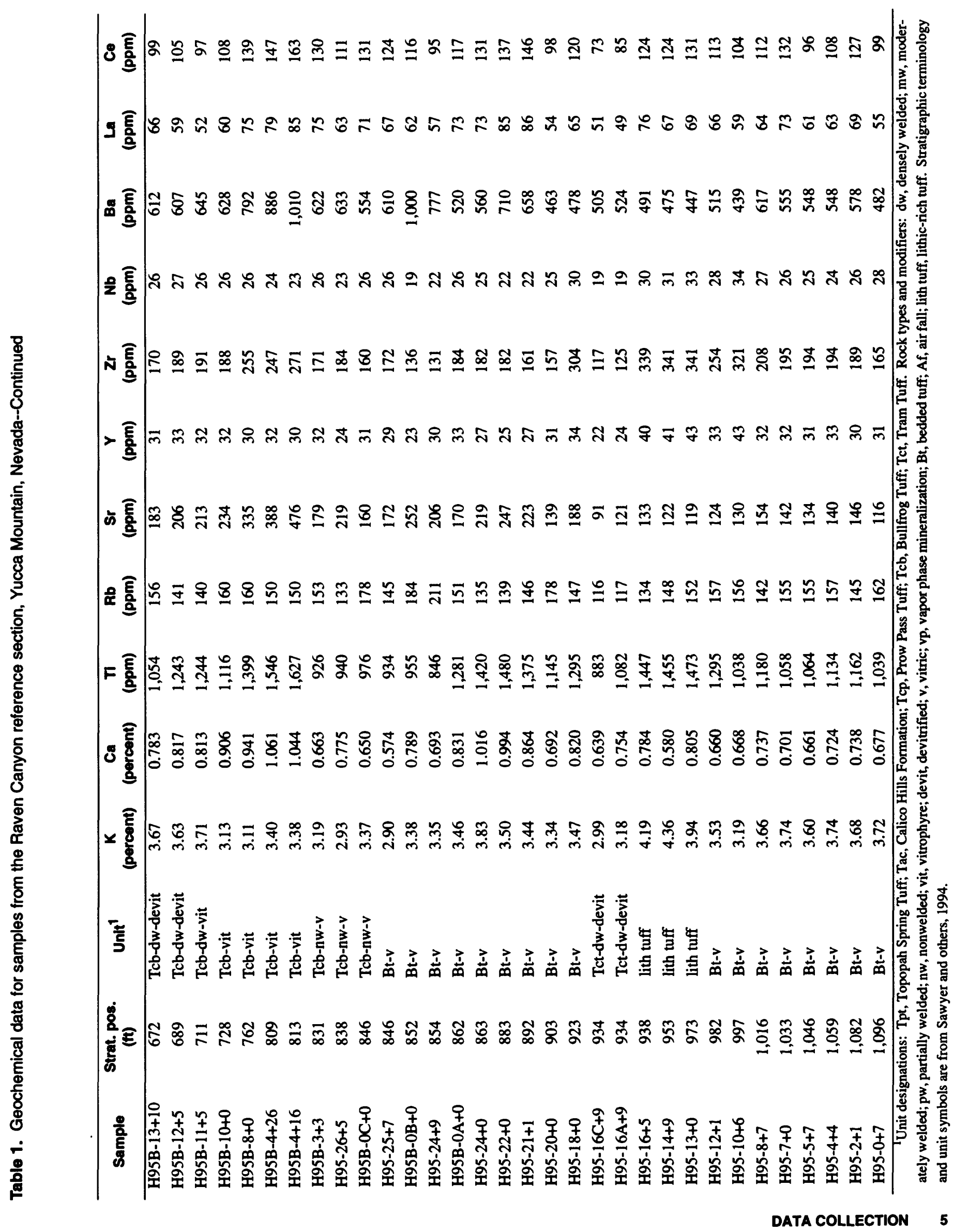




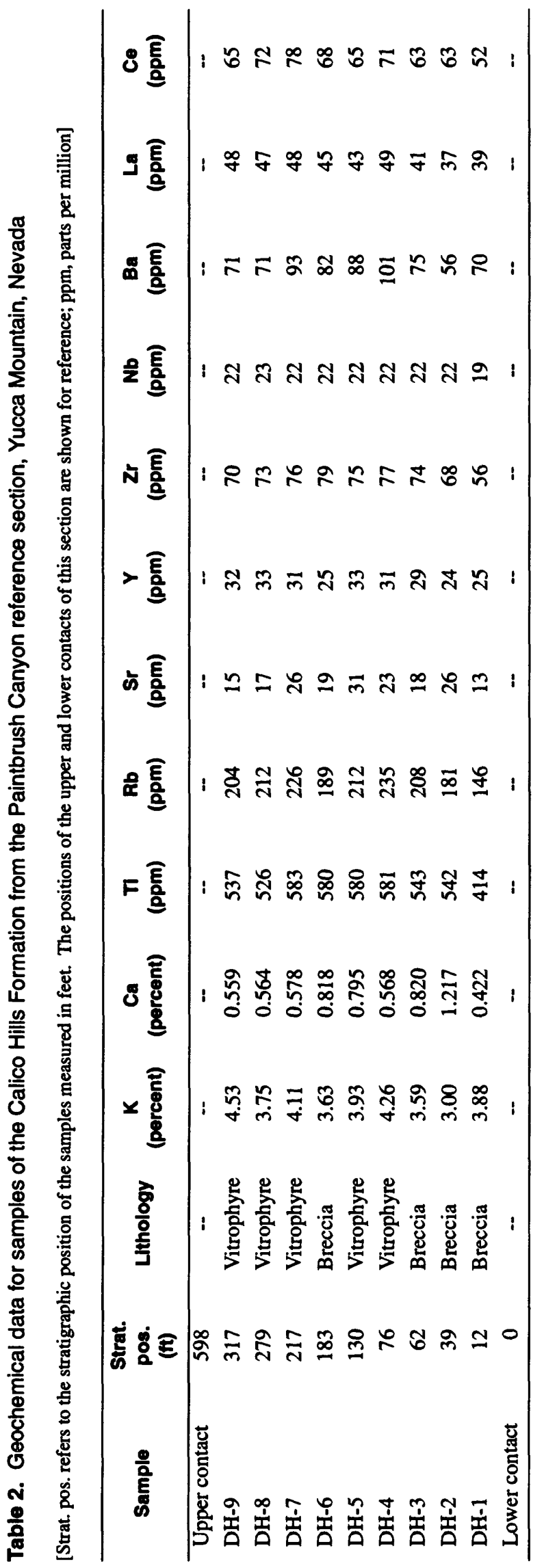


Strontium-isotope compositions were determined by thermal ionization mass spectrometry on representative samples from the Raven Canyon and Paintbrush Canyon reference sections (table 3) using conventional dissolution and mass spectrometric procedures described previously (Peterman and others, 1985). All ${ }^{87} \mathrm{Sr} /{ }^{86} \mathrm{Sr}$ values were adjusted to a scale on which the value for modern sea water is 0.70920 as determined by analyses of standard EN-1 which was prepared from the shell of a modern tridacna collected from Enewetok Atoll in the western Pacific Ocean.

Relative to the standard, the ${ }^{87} \mathrm{Sr} /{ }^{86} \mathrm{Sr}$ values are accurate to better than \pm 0.01 percent (95-percent confidence level) of the value reported.

\section{GEOCHEMISTRY OF OUTCROP SAMPLES}

The geochemical data (table 1) for samples from the Raven Canyon reference section are presented in graphs showing element concentrations and ratios as a function of stratigraphic position of the samples. Geochemical data for samples from the Calico Hills Formation (table 2) are presented in tabular form only, and isotopic data for samples from both sections (table 3 ) are presented as a composite section.

Geochemical variations within the Topopah Spring Tuff reflect the first-order lithologic variations described by Lipman and others (1966). The lower two-thirds to three-quarters of the unit is devitrified, densely welded, crystal-poor, high-silica rhyolite

Table 3. Strontium-isotope data for samples from the Raven Canyon and Paintbrush Canyon reference sections

[The Calico Hills Formation of the Paintbrush Canyon section is shown in its appropriate stratigraphic position (strat. pos.) relative to the Raven Canyon section]

\begin{tabular}{llcccc}
\hline \multicolumn{1}{c}{ Sample } & \multicolumn{1}{c}{ Unit' } & $\begin{array}{c}\text { Strat. pos. } \\
\text { (ft) }\end{array}$ & ${ }^{\mathbf{8 7}_{\mathbf{R b}} \mathbf{p 6}^{\mathbf{S}} \mathbf{S r}}$ & ${ }^{\mathbf{8 7}} \mathbf{S r}^{\mathbf{8 6}} \mathbf{S r}$ & IR(Sr) \\
\hline H95C-18-7 & Tpt-nw-v & 118 & 25.05 & 0.71649 & 0.71194 \\
DH-9 & Tac-vit & 125 & 38.87 & 0.71764 & 0.71052 \\
DH-8 & Tac-vit & 171 & 35.29 & 0.71782 & 0.71136 \\
DH-5 & Tac-vit & 584 & 19.99 & 0.71493 & 0.71127 \\
DH-4 & Tac-vit & 814 & 29.59 & 0.71689 & 0.71147 \\
DH-3 & Tac-breccia & 869 & 33.46 & 0.71686 & 0.71073 \\
H95C-14+6 & Tcp-nw-v & 1,014 & 7.85 & 0.71199 & 0.71054 \\
H95C-10-16 & Tcp-pw-vp & 1,089 & 8.43 & 0.71207 & 0.71051 \\
H95C-7+10 & Tcp-nw-vp & 1,148 & 8.68 & 0.71218 & 0.71058 \\
H95C-4+4 & Tcp-nw-vp & 1,211 & 8.19 & 0.71214 & 0.71063 \\
H95C-1+0 & Tcp-nw-v & 1,273 & 9.27 & 0.71116 & 0.70945 \\
H95C-0-10 & Tcp-nw-v & 1,289 & 10.40 & 0.71208 & 0.71016 \\
H95C-0-1 & AF-v & 1,293 & 4.30 & 0.71134 & 0.71055 \\
H95B-24+0 & Tcb-nw-v & 1,322 & 2.69 & 0.70924 & 0.70874 \\
H95B-18-0 & Tcb-pw-vp & 1,404 & 2.70 & 0.70920 & 0.70870 \\
H95B-14-35 & Tcb-dw-d & 1,467 & 2.66 & 0.70909 & 0.70860 \\
H95B-11-5 & Tcb-dw-v & 1,532 & 1.90 & 0.70872 & 0.70837 \\
H95B-4+26 & Tcb-v & 1,631 & 1.12 & 0.70828 & 0.70807 \\
H95B-0C+0 & Tcb-nw-v & 1,667 & 3.22 & 0.70933 & 0.70873 \\
H95-22+0 & Bt-v-m & 1,706 & 1.63 & 0.70942 & 0.70911 \\
H95-18+0 & Bt-v-m & 1,745 & 2.26 & 0.71270 & 0.71227 \\
H95-16+5 & lith tuff & 1,759 & 2.80 & 0.71013 & 0.70959 \\
H95-10+6 & Bt-v & 1,818 & 3.47 & 0.70993 & 0.70926 \\
H95-5+7 & Bt-v & 1,867 & 3.35 & 0.71025 & 0.70961 \\
\hline
\end{tabular}

${ }^{1}$ Unit abbreviations are the same as in table 1 . 
consisting largely of microcrystalline quartz and feldspar. The high-silica rhyolite is overlain by quartz latite separated by an interval that is transitional in composition upward due to mixing of high-silica rhyolite and quartz latite (Schuraytz and Vogel, 1989). The upper three samples of the Topopah Spring Tuff at the Raven Canyon reference section are from the quartz latitic caprock and vitrophyre (table 1). The increase in $\mathrm{Zr}$ and $\mathrm{Ti}$ (fig. 2), $\mathrm{Ca}, \mathrm{Sr}$, and $\mathrm{Ba}$ (fig. 3), $\mathrm{La}$ and $\mathrm{Ce}$ (fig. 4), and decrease in $\mathrm{Rb}$ and $\mathrm{Nb}$ (fig. 5) upward in the unit are characteristic features of the quartz latite (Peterman and others, 1991). In contrast, the subjacent high-silica rhyolite is remarkably uniform in composition. These internal geochemical features are characteristic of the Topopah Spring Tuff throughout its extent at Yucca Mountain. The younger Tiva Canyon Tuff has a similar internal compositional zonation (Peterman and Futa, in press). These first-order geochemical and lithologic features of the Topopah Spring and Tiva Canyon Tuffs are the inverse reflection of compositional gradients in their source magmas. Locally, the Topopah Spring Tuff has been altered to zeolites and clay in a zone at the top of the lower vitrophyre (Levy and O'Neil, 1989; Peterman and others, 1991). In drill hole UE-25a \#1, this altered zone is marked by substantial increases in $\mathrm{Sr}$ and $\mathrm{Ca}$ contents. Corresponding increases in $\mathrm{Ti}$ and $\mathrm{Zr}$ in this zone indicate that these elements can be mobilized during intense alteration of glassy rock where they are not securely sequestered in discrete minerals (Peterman and others, 1991). This localized alteration in the Topopah Spring Tuff is not present at the Raven Canyon reference section (figs. 2 and 3 ).

The Wahmonie Formation in the Raven Canyon reference section is represented by nonwelded to partially welded bedded tuffs, and the three samples collected show large variations in the concentrations of $\mathrm{Zr}$, $\mathrm{Ti}, \mathrm{Ca}, \mathrm{Sr}$, and $\mathrm{Ba}$, (figs. 2 and 3). Detailed sampling and analyses are needed to characterize this unit.

The Prow Pass Tuff at Raven Canyon consists of a central zone of partially welded tuffs displaying vapor-phase mineralization overlain and underlain by nonwelded vitric zones. The concentrations of $\mathrm{Ca}, \mathrm{Sr}$, and $\mathrm{Ba}$ (fig. 3) are remarkably uniform throughout the unit irrespective of the zonal variations. For example, the total range in Ba of 277 to $291 \mathrm{ppm}$ (micrograms of element/gram of sample) throughout the unit is well within analytical error. The minor variations in $\mathrm{Sr}$ (50 to $66 \mathrm{ppm})$ and $\mathrm{Ca}(0.52$ to 0.68 percent) are correlative (figs. 3 and 6). Zirconium ranges from 149 to $194 \mathrm{ppm}$ with the highest value in a nonwelded vitric sample at the base, and $\mathrm{Ti}$, ranging from 614 to $713 \mathrm{ppm}$, may increase slightly with depth. A step increase in $\mathrm{K}$ upward is accompanied by a step decrease in $\mathrm{Rb}$ between samples to 406 and $428 \mathrm{ft}$ (fig. 5) resulting in a step increase upward in $\mathrm{K} / \mathrm{Rb}$ ratios (fig. 6).

The Bullfrog Tuff consists of nonwelded vitric tuffs that are underlain by partially to moderately welded tuffs containing vapor-phase mineralization and by densely welded, devitrified tuffs. The lower part of the unit consists of vitrophyre underlain by nonwelded vitric tuff. These zonal variations in welding and crystallization are accompanied by systematic downward increases in $\mathrm{Ti}, \mathrm{Zr}, \mathrm{Ca}, \mathrm{Sr}, \mathrm{Ba}, \mathrm{La}$, and $\mathrm{Ce}$ followed by marked decreases in these elements in the nonwelded, vitric tuffs at the base (figs. 2, 3, and 4). In contrast, $\mathrm{K}, \mathrm{Nb}, \mathrm{Rb}$, and $\mathrm{Y}$ are relatively uniform throughout the unit (figs. 4 and 5). These variations may be primary or may indicate incipient alteration of the vitrophyre perhaps similar to that which occurs in the lower part of the Topopah Spring Tuff (Peterman and others, 1991).

The relatively thin Tram Tuff at Raven Canyon consists of densely welded, devitrified tuff underlain by lithic-rich tuff. The densely welded, devitrified tuff has much smaller concentrations of $\mathrm{Zr}, \mathrm{Ti}, \mathrm{K}, \mathrm{Rb}, \mathrm{Nb}$, Y, La, and Ce (figs. 2, 4, and 5) than the underlying lithic-rich tuff. The densely welded and lithic-rich tuffs are similar in alkaline-earth element concentrations (fig. 3). Most of the element concentrations scatter considerably in the bedded vitric tuffs that overlie and underlie the Tram Tuff (figs. 2-5).

The Calico Hills Formation, although not present at Raven Canyon, is extensive beneath most of Yucca Mountain where it has been zeolitized (Broxton and others, 1987). However, vitric tuffs of the Calico Hills Formation occur in an area between Yucca Wash and Fortymile Wash (Dickerson and Hunter, 1994), and a well-exposed sequence in Paintbrush Canyon was selected as a geochemical reference section (fig. 1). In this area, the Calico Hills Formation is composed of an alternating tuff breccia, bedded tuff, and vitrophyric rhyolite.

Nine samples of the Calico Hills Formation were collected from a stratigraphic interval of approximately $300 \mathrm{ft}$; these samples are limited in their compositional range (table 2). Peterman and others (1993) compared these vitric tuffs with samples of the zeolitized tuffs of the Calico Hills Formation penetrated by drill holes UE-25a \#1 and UE-25b \#1. Zeolitization was accompanied by large-scale open-system behavior in $\mathrm{Ca}$ and $\mathrm{Sr}$ whereas $\mathrm{Zr}$ and $\mathrm{Ti}$ were relatively immobile. The composition of the vitric Calico Hills Formation is similar in many respects to that of the high-silica rhyolite of the Topopah Spring Tuff at Raven Canyon and to the high-silica rhyolite of the Tiva Canyon Tuff in drill hole UE-NRG\#3 (Peterman and Futa, in press). The 


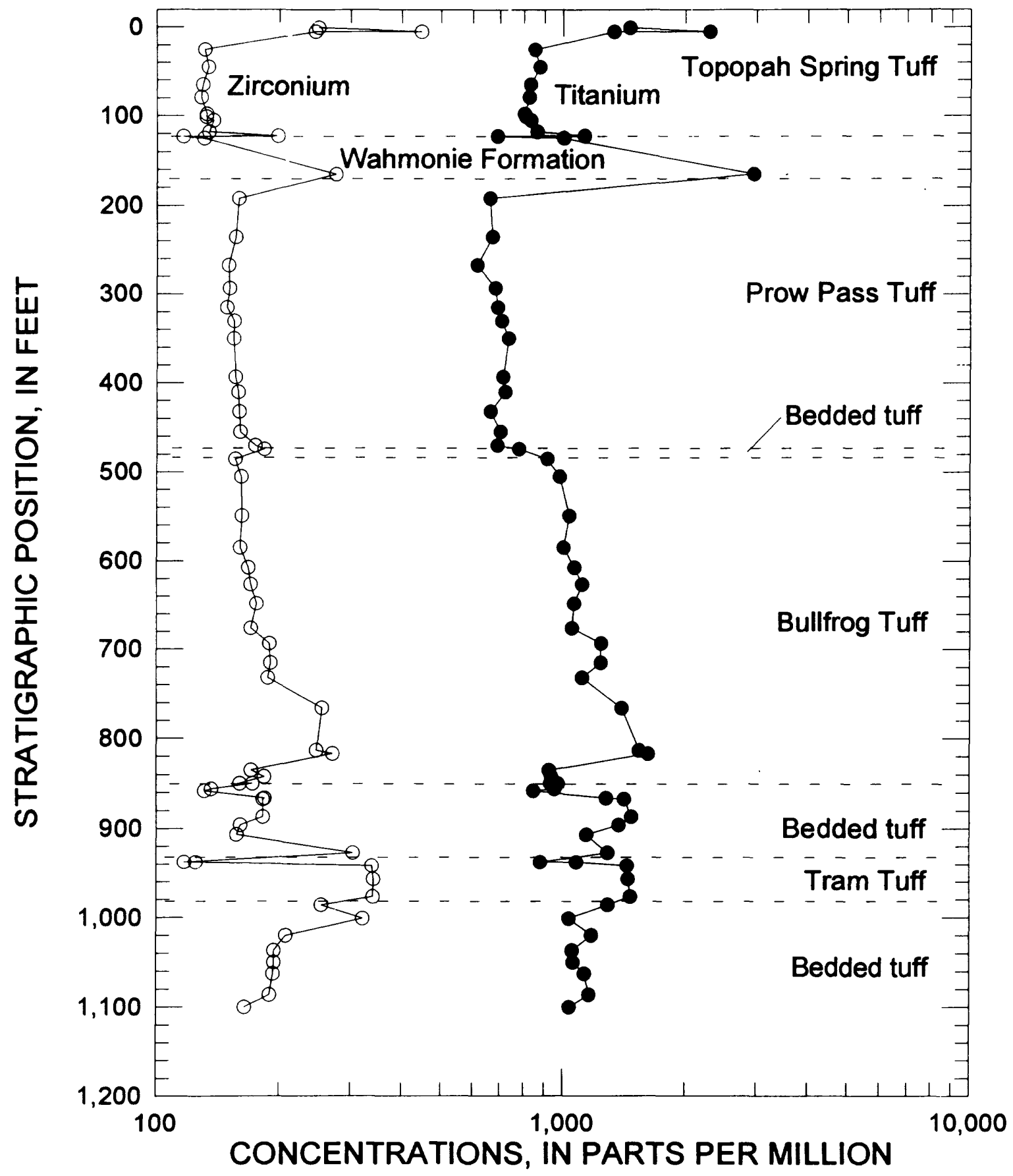

Flgure 2. Concentrations of zirconium and titanium in samples from the Raven Canyon reference section. 


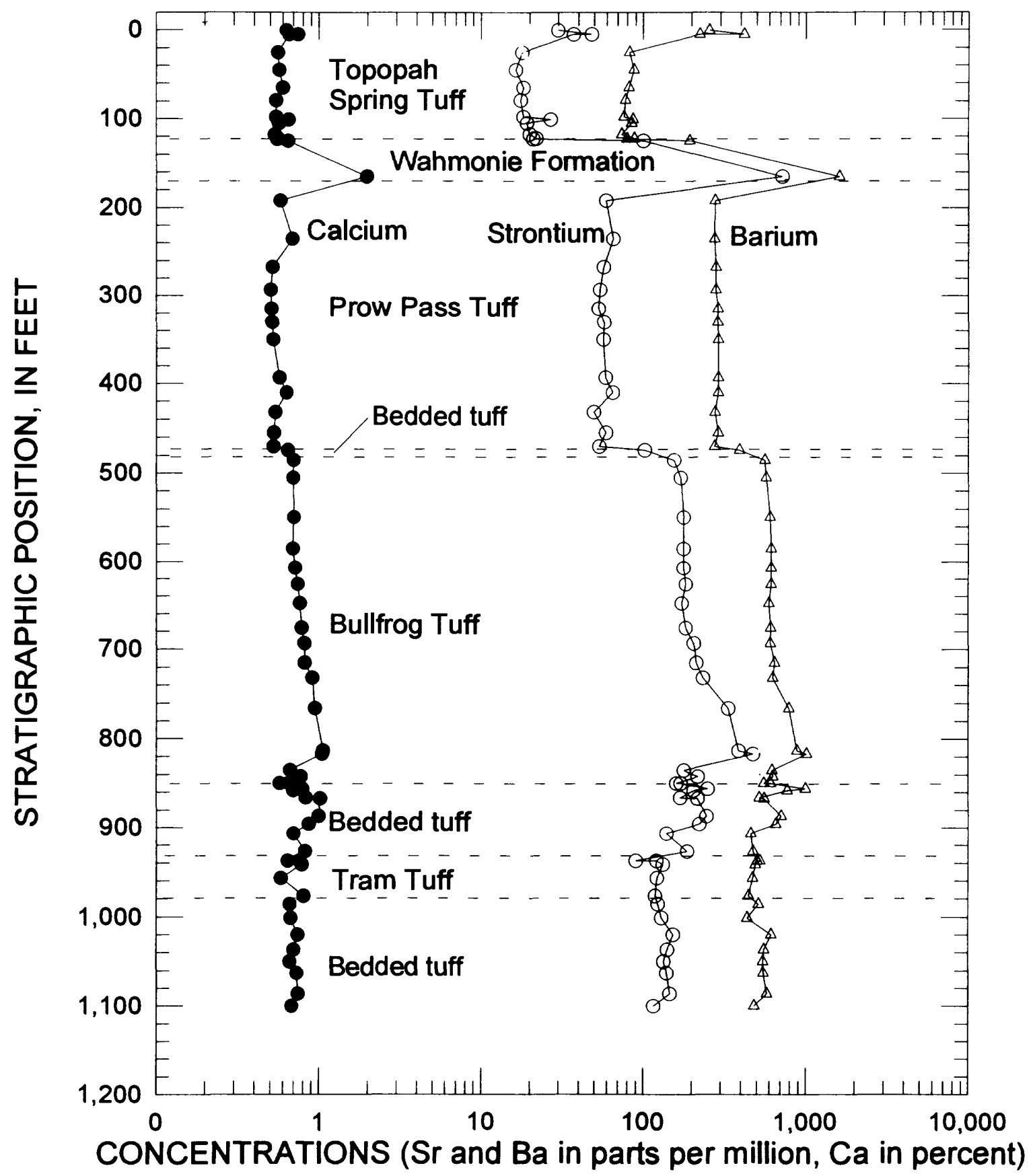

Figure 3. Concentrations of calcium, strontium, and banium in samples from the Raven Canyon reference section. 


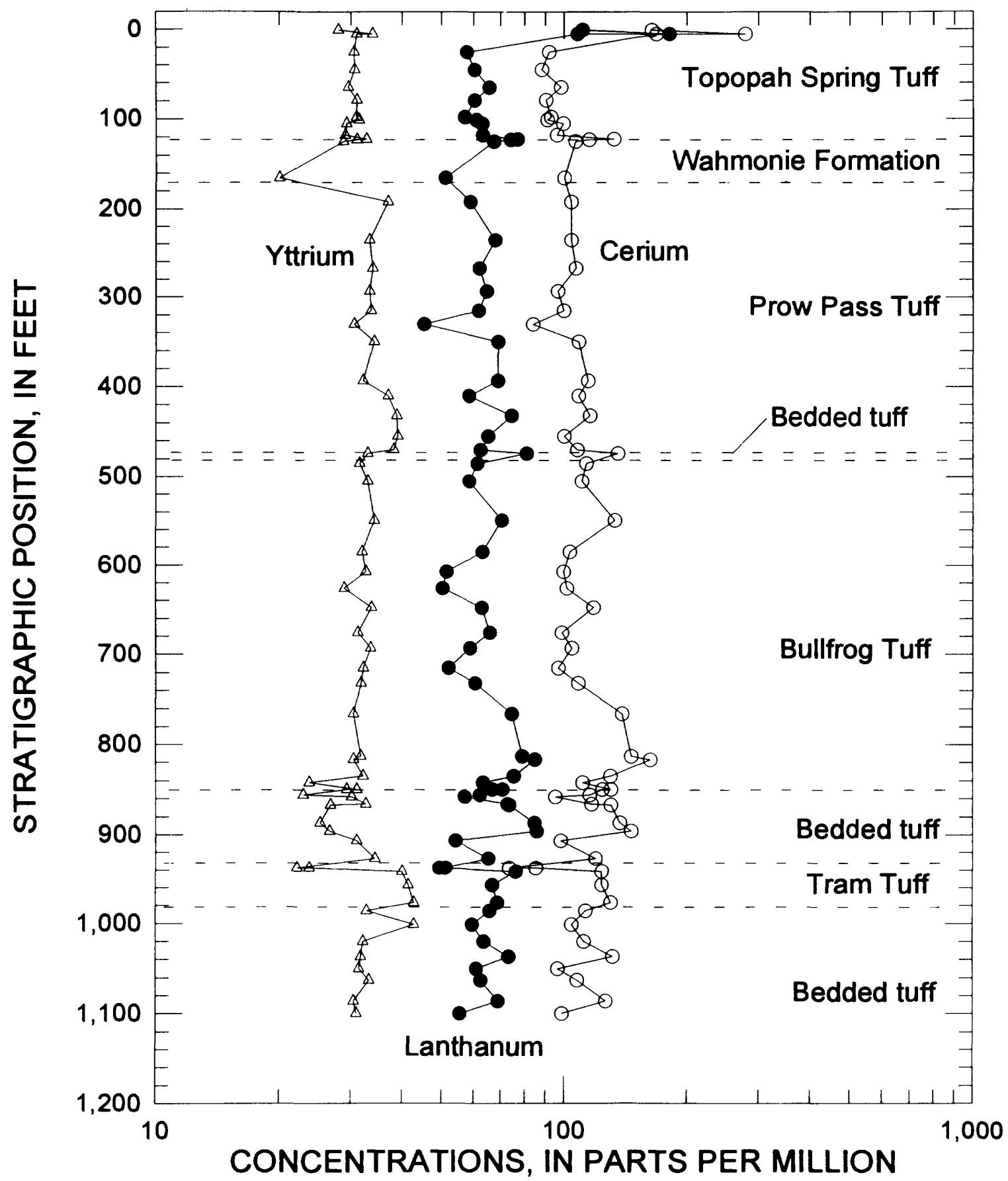

Figure 4. Concentrations of yttrium, lanthanum, and cerium in samples from the Raven Canyon reference section. 


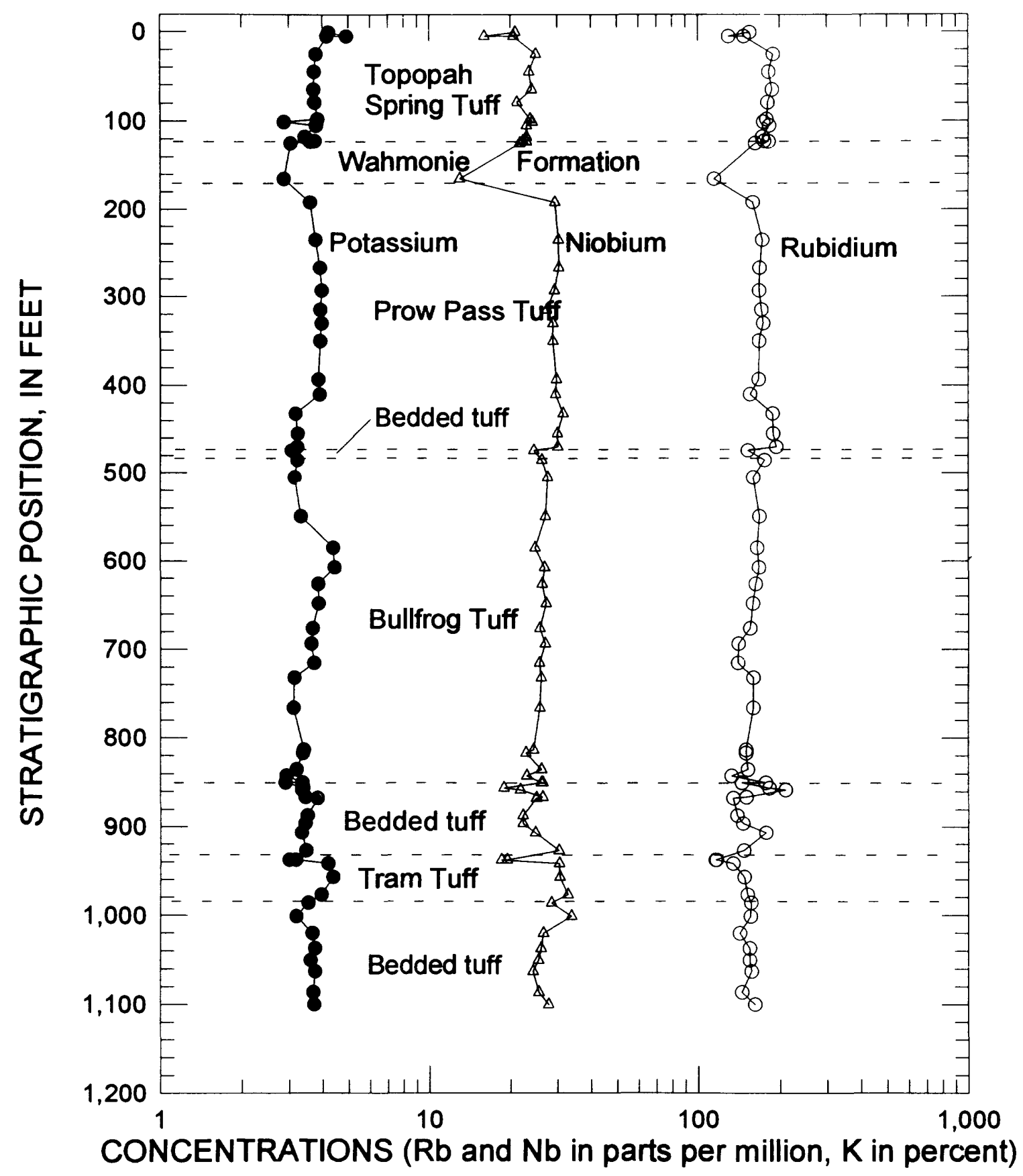

Figure 5. Concentrations of potassium, niobium, and rubidium in samples from the Raven Canyon reference section. 


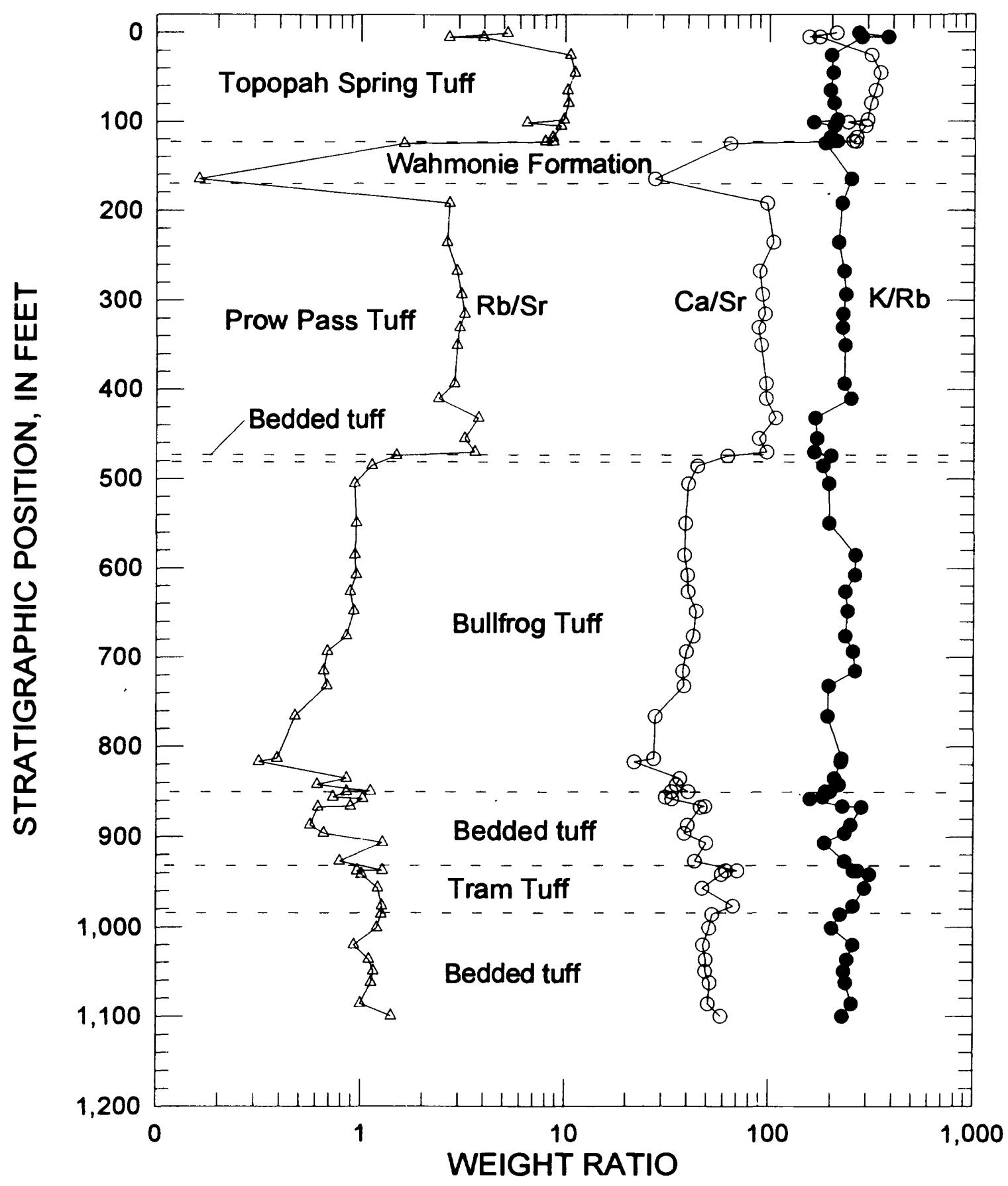

Figure 6. Ratios of rubidium to strontium ( $\mathrm{Rb} / \mathrm{Sr}$ ), calcium to strontium $(\mathrm{Ca} / \mathrm{Sr}$ ), and potassium to rubidium (K/Rb) in samples from the Raven Canyon reference section. 
most important difference is in the much lower $\mathrm{Zr}$ concentration ( 56 to $79 \mathrm{ppm}$ ) of the Calico Hills Formation (table 2) compared with the high-silica rhyolites of the younger units (approximately 130 ppm for the Topopah Spring Tuff and $200 \mathrm{ppm}$ for the Tiva Canyon Tuff).

Strontium isotope measurements were completed on selected samples from the Raven Canyon and Paintbrush Canyon reference sections. Data for the Calico Hills Formation have been integrated with data for samples from Raven Canyon to form a composite section for illustrative purposes (fig. 7). The nonwelded vitric zones near the contacts of the Prow Pass and Bullfrog Tuffs show considerable isotopic variation (fig. 7) which may indicate alteration related to localized fluid flow along these more conductive zones.

The general decrease down section in measured present-day and calculated initial ${ }^{87} \mathrm{Sr} /{ }^{86} \mathrm{Sr}$ values (fig. 7) is consistent with results obtained on composite samples prepared from USW G-1 core (Spengler and Peterman, 1991). The high initial ${ }^{87} \mathrm{Sr} /{ }^{86} \mathrm{Sr}$ ratio, designated IR(Sr), for the sample of high-silica rhyolite from the Topopah Spring Tuff is characteristic of this unit where it is relatively unaltered. For example, 16 samples of the Topopah Spring high-silica rhyolite from drill hole USW G-4 have a narrow range in $\mathrm{IR}(\mathrm{Sr})$ values and a mean and standard deviation of $0.71284 \pm 0.00019$ (Z.E. Peterman, unpub. data, 1994). The range in Sr contents and mean IR(Sr) values $( \pm 1 \sigma)$ for the units in the Raven Canyon and Paintbrush Canyon reference sections are: Calico Hills Formation, 15 to $31 \mathrm{ppm}, 0.71107 \pm 0.00037$; Prow Pass Tuff, 54 to $59 \mathrm{ppm}, 0.71031 \pm 0.00044$; and Bullfrog Tuff, 156 to $476 \mathrm{ppm}, 0.70853 \pm 0.00024$. These systematic geochemical and isotopic variations are features that relate to the origin and crustal contamination of the source magmas. The IR(Sr) values for all samples are plotted against the reciprocal of the Sr concentrations in figure 8. Disregarding the point in the upper lefthand corner of the graph, which represents a bedded tuff, the data clearly indicate two trends. Linear arrays of data on a plot of this type commonly indicate mixing of two end members. Samples that have $1 / \mathrm{Sr}$ values of less than 0.01 ( $\mathrm{Sr}$ concentrations greater than $100 \mathrm{ppm}$ ) plot close to a steep line that is labeled "Mixing (Assimilation)." This array probably indicates mixing (through assimilation) of primitive, mantle-derived magma (high $\mathrm{Sr}$ concentrations and $10{ }^{87} \mathrm{Sr} /{ }^{86} \mathrm{Sr}$ ) with Precambrian crustal material (lower $\mathrm{Sr}$ concentrations with higher ${ }^{87} \mathrm{Sr} /{ }^{86} \mathrm{Sr}$ ). The data to the right of the steep mixing line in figure 8 are largely data for samples of the Prow Pass Tuff and the Calico Hills Formation. Fractional crystallization without assimilation would result in migration of the liquid composition away from a point on the steep curve to lower Sr concentration values with no change in the IR(Sr) values. The horizontal line labeled "Differentiation" is the locus of one possible path that could result from fractional crystallization involving plagioclase or sanidine removal, or both, and concomitant depletion of the residual liquid in $\mathrm{Sr}$.

\section{CONCLUSIONS}

- Samples of densely welded, devitrified tuff from relatively unaltered intervals of the Raven Canyon and Paintbrush Canyon reference sections have trace element concentrations and $\mathrm{Sr}$ isotope ratios showing only slight variability or reflecting internal lithologic variations that are primary features inherited from compositionally and isotopically zoned magmas.

- At the Raven Canyon reference section, the greatest degree of element variability is within nonwelded tuffs between the major units. This variability probably indicates water-rock interaction along these more transmissive units.

- The thick lower vitrophyre of the Bullfrog Tuff at Raven Canyon displays systematic increases in $\mathrm{Ti}, \mathrm{Zr}, \mathrm{Ca}, \mathrm{Sr}, \mathrm{Ba}, \mathrm{La}$, and $\mathrm{Ce}$ concentrations downward compared with concentrations in the overlying densely welded, devitrified portion of the unit. These variations may be primary or may indicate incipient alteration of the vitrophyre perhaps similar to the localized alteration in the lower part of the Topopah Spring Tuff.

- Data in this report for unaltered tuffs at reference sections at Raven Canyon and Paintbrush Canyon can be used as baseline information for geochemical and isotopic studies of the rock mass at Yucca Mountain. Such data can be of value in correlating zonal features within the volcanic units in drill holes and in the Experimental Studies Facility (ESF). This baseline data can also contribute significantly to developing an understanding of the degree and extent of element mobility in the past. By analogy, this information can be useful in assessing possible future alteration in the Topopah Spring Tuff that might be induced by heating and mobilization of water liberated from nearby zeolitized zones. 


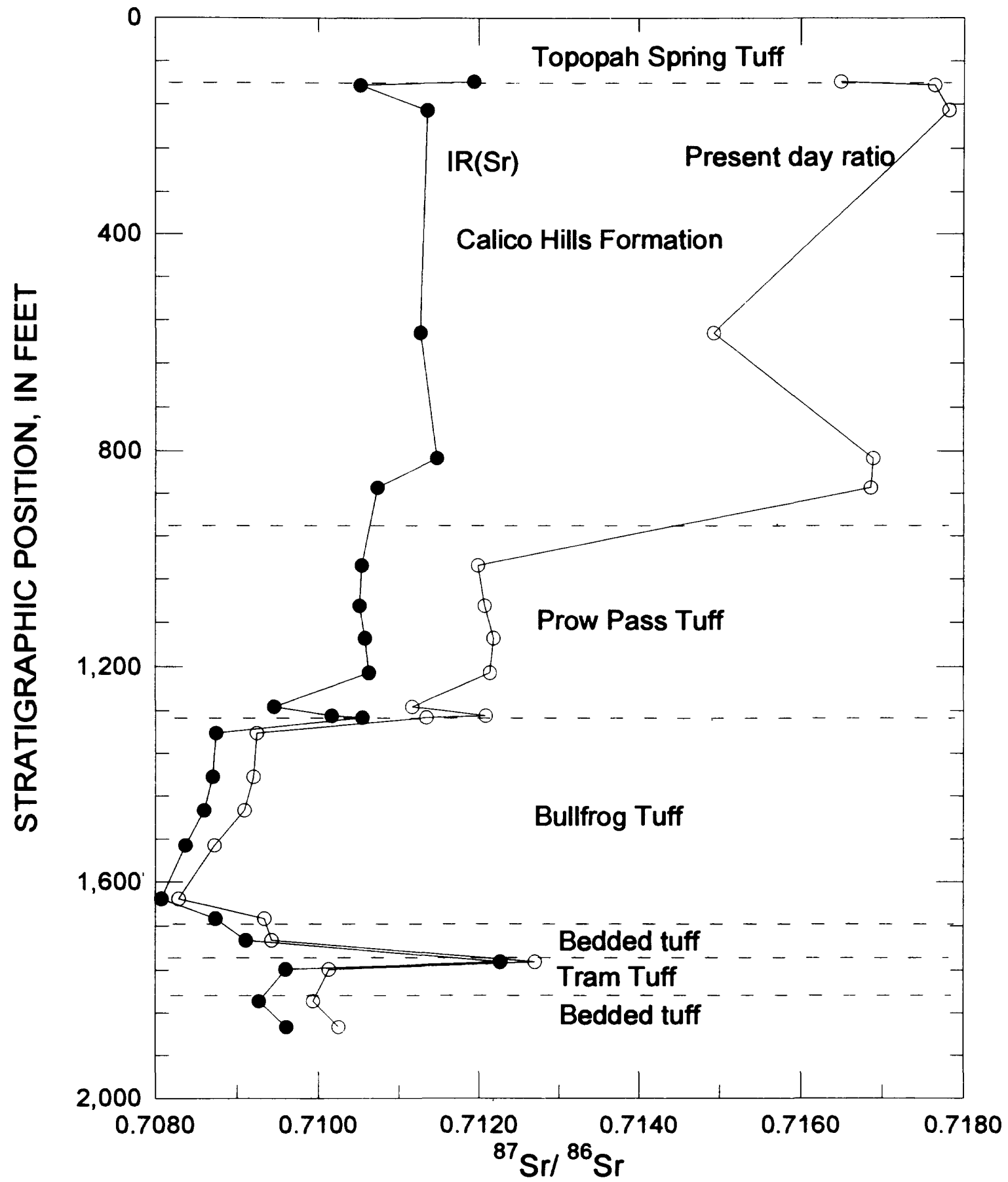

Figure 7. Present-day and initial ${ }^{87} \mathrm{Sr}{ }^{\beta 6} \mathrm{Sr}$ values for samples from the Raven Canyon and Paintbrush Canyon reference sections. 


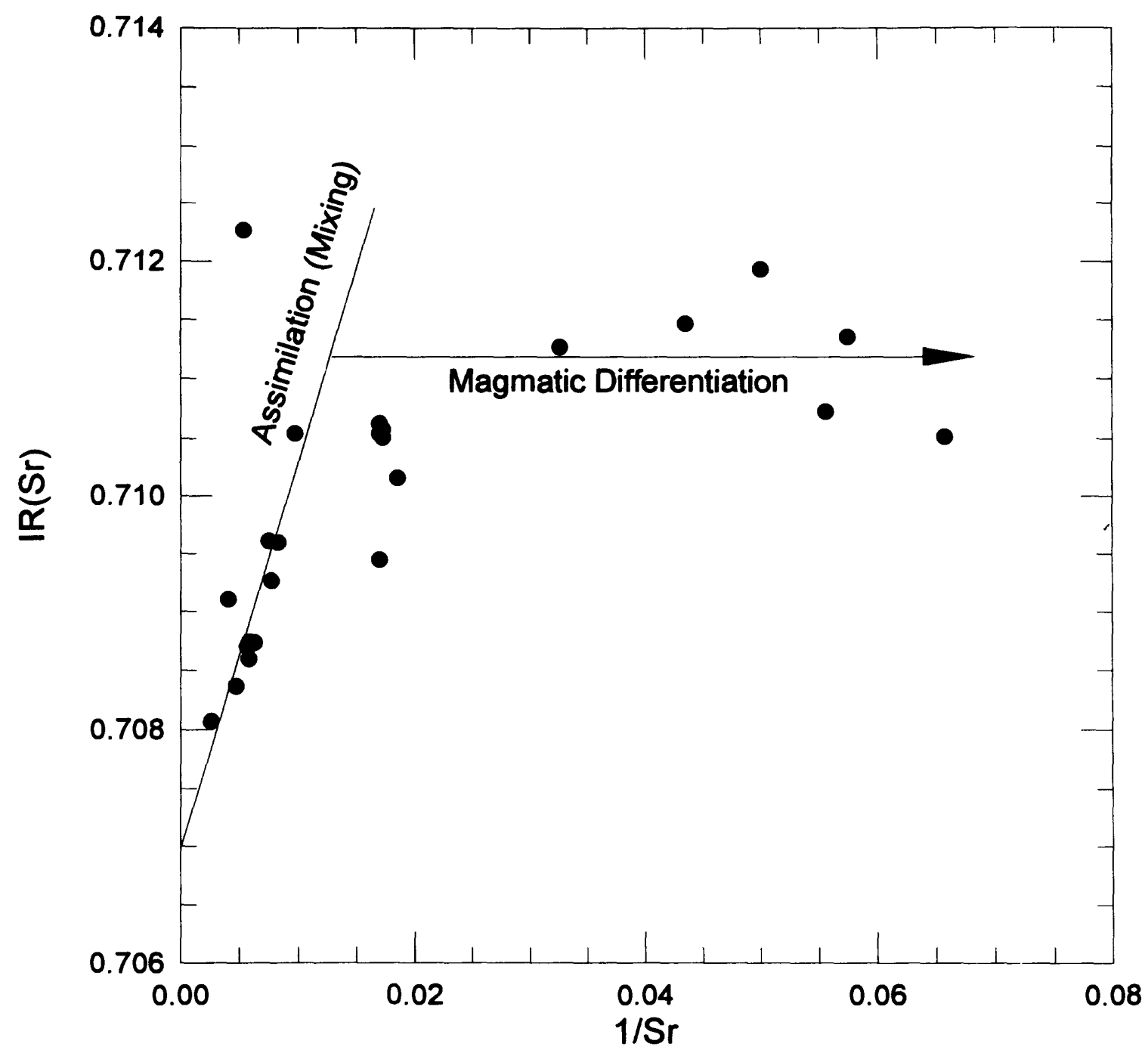

Figure 8. IR(Sr) values versus reciprocal strontium concentrations for samples from the Raven Canyon and Paintbrush Canyon reference sections. 


\section{REFERENCES CITED}

Bish, D.L., 1990, Thermal stability of zeolitic tuff from Yucca Mountain, Nevada, in High Level Radioactive Waste Management, 1st, Las Vegas, NV, 1990, Proceedings: La Grange Park, IL, American Nuclear Society and American Society of Civil Engineers, p. 596-602.

Broxton, D.E., 1992, Chemical changes associated with zeolitization of the tuffaceous beds of Calico Hills, Yucca Mountain, Nevada, in Kharaka, Y.K., and Maest, A.S., eds., Water Rock Interaction: Rotterdam, A.A., Balkama, v. 1, p. 699-703.

Broxton, D.E., Bish, D.L., and Warren, R.G., 1987, Distribution and chemistry of diagenetic minerals at Yucca Mountain, Nye County, Nevada: Clays and Clay Mineralogy, v. 35, p. 89-110.

Dickerson, R.P., and Hunter, W.C., 1994, Evidence for a welded tuff in the rhyolite of Calico Hills, in High Level Radioactive Waste Management, 5th, Las Vegas, NV, 1994, Proceedings: La Grange Park, IL, American Nuclear Society and American Society of Civil Engineers, p. 1861-1868.

Herbst, R.J., and Canepa, J.A., 1989, Assessment of radionuclide retardation: Radioactive Waste Management and the Nuclear Fuel Cycle, v. 13, p. 77-92.

Levy, S.S., and O'Neil, J.R., 1989, Moderate-temperature zeolitic alteration in a cooling pyroclastic unit: Chemical Geology, v. 76, p. 321-326.

Lipman, P. W., Christiansen, R.L., and O'Connor, J.T., 1966, A compositionally zoned ash-flow sheet in southern Nevada: U.S. Geological Survey Professional Paper 524-F, $47 \mathrm{p}$.

Peterman, Z.E., and Futa, Kiyoto, 1994, Geochemistry of core samples of the Tiva Canyon Tuff from drill hole NRG\#3: U.S. Geological Survey Open-File Report 95-325, 19 p.

Peterman, Z.E., Sims, P.K., Zartman, R.E., and Schulz, K.J., 1985, Middle Proterozoic uplift events in the Dunbar dome of northeastern Wisconsin, USA: Contributions to Mineralogy and Petrology, v. 91, p. 138-150.

Peterman, Z.E., Spengler, R.W., Futa, Kiyoto, Marshall, B.D., and Mahan, Shannon, 1991, Assessing the natural performance of felsic tuffs using the $\mathrm{Rb}-\mathrm{Sr}$ and $\mathrm{Sm}$-Nd systems-A study of the altered zone in the Topopah Spring Member, Paintbrush Tuff, Yucca
Mountain, Nevada, in Abrajano, T., Jr., and Johnson, L.H., eds., Scientific basis for waste management XIV: Pittsburgh, Material Research Society, v. 212, p. 687-694.

Peterman, Z.E., Spengler, R.W., Singer, F.R., and Dickerson, R.P., 1993, Isotopic and trace element variability in altered and unaltered tuffs at Yucca Mountain, Nevada in High Level Radioactive Waste Management, 4th, Las Vegas, NV, 1993, Proceedings: La Grange Park, IL, American Nuclear Society and American Society of Civil Engineers, p. 1940-1947.

Sawyer, D.A., Fleck, R.J., Lanphere, M.A., Warren, R.G., Broxton, D.E., and Hudson, M.R., 1994, Episodic caldera volcanism in the Miocene southwestern Nevada volcanic field-Revised stratigraphic framework, ${ }^{40} \mathrm{Ar} /{ }^{39} \mathrm{Ar}$ geochronology, and implications for magmatism and extension: Geological Society of America Bulletin, v. 106, no. 10, p. 1304-1318.

Schuraytz, B.C., and Vogel, T.A., 1989, Evidence of dynamic withdrawal from a layered magma body - The Topopah Spring Tuff, southwestern Nevada: Journal of Geophysical Research, v. 94, p. 5925-5942.

Spengler, R.W., and Fox, K.F., Jr., 1989, Stratigraphic and structural framework of Yucca Mountain, Nevada: Radioactive Waste Management and the Nuclear Fuel Cycle, v. 13, p. 21-36.

Spengler, R.W., and Peterman, Z.E., 1991, Distribution of rubidium, strontium, and zirconium in tuff from two deep coreholes at Yucca Mountain, Nevada, in High Level Radioactive Waste Management, 2nd, Las Vegas, NV, 1991, Proceedings: La Grange Park, IL, American Nuclear Society and American Society of Civil Engineers, p. 1416-1422.

U.S. Department of Energy, 1988, Site characterization plan, Yucca Mountain site, Nevada research and development area, Nevada: U.S. Department of Energy Report DOE RW/0199, v. 9, various pagination.

WoldeGabriel, Giday, Broxton, D.E., Bish, D.L., and Chipera, S.J., 1992, Preliminary assessment of clinoptolilite K-Ar results from Yucca Mountain, Nevada, USA-A potential high-level radioactive waste repository site, in Kharaka, Y.K., and Maest, A.S., eds., Water Rock Interaction: Rotterdam, A.A. Balkama, v. 1, p. $457-461$. 